\title{
Transactions
}

\section{Self-assembly of hybrid organic-inorganic polyoxovanadates: functionalised mixed-valent clusters and molecular cages $\uparrow$}

\author{
John M. Breen, ${ }^{a}$ Rodolphe Clérac, ${ }^{b, c}$ Lei Zhang, ${ }^{a}$ Suzanne M. Cloonan, $\mathfrak{t}^{d}$ Elaine Kennedy, ${ }^{d}$ Martin Feeney, ${ }^{a}$ \\ Thomas McCabe, ${ }^{a} \mathrm{D}$. Clive Williams ${ }^{d}$ and Wolfgang Schmitt* ${ }^{a}$
}

Received 20th June 2011, Accepted 24th November 2011

DOI: 10.1039/c2dt11153e

Herein we report the intra- and inter-molecular assembly of a $\left\{\mathrm{V}_{5} \mathrm{O}_{9}\right\}$ subunit. This mixed-valent structural motif can be stabilised as $\left[\mathrm{V}_{5} \mathrm{O}_{9}\left(\mathbf{L}_{1-3}\right)_{4}\right]^{5-/ 9-}(\mathbf{1}-\mathbf{3})$ by a range of organoarsonate ligands $\left(\mathbf{L}_{1}-\mathbf{L}_{3}\right)$ whose secondary functionalities influence its packing arrangement within the crystal structures. Variation of the reaction conditions results in the dodecanuclear cage structure $\left[\mathrm{V}_{12} \mathrm{O}_{14}(\mathrm{OH})_{4}\left(\mathbf{L}_{1}\right)_{10}\right]^{4-}(4)$ where two modified convex building units are linked via two dimeric $\left\{\mathrm{O}_{4} \mathrm{~V}^{\mathrm{IV}}(\mathrm{OH})_{2} \mathrm{~V}^{\mathrm{IV}} \mathrm{O}_{4}\right\}$ moieties. Bi-functional phosphonate ligands, $\mathbf{L}_{\mathbf{4}}-\mathbf{L}_{\mathbf{6}}$ allow the intramolecular connectivity of the $\left\{\mathrm{V}_{5} \mathrm{O}_{9}\right\}$ subunit to give hybrid capsules $\left[\mathrm{V}_{10} \mathrm{O}_{18}\left(\mathbf{L}_{\mathbf{4}-6}\right)_{4}\right]^{10-}{ }_{(\mathbf{5}-7)}$. The dimensions of the electrophilic cavities of the capsular entities are determined by the incorporated ligand type. Mass spectrometry experiments confirm the stability of the complexes in solution. We investigate and model the temperature-dependent magnetic properties of representative complexes $1,4,6$ and 7 and provide preliminary cell-viability studies of three different cancer cell lines with respect to $\mathrm{Na}_{8} \mathrm{H}_{2}[6] \cdot 36 \mathrm{H}_{2} \mathrm{O}$ and $\mathrm{Na}_{8} \mathrm{H}_{2}[7] \cdot 2 \mathrm{DMF} \cdot 29 \mathrm{H}_{2} \mathrm{O}$.

\section{Introduction}

The synthesis and characterisation of novel functionalised polyoxometalate (POM) clusters is a current and vibrant research field. ${ }^{1}$ The interest in POM-based materials arises from their intrinsic physicochemical attributes which prompt applications in areas such as catalysis, electronics, medicine, environmental sciences, gas storage and energy conversion. ${ }^{2}$ Polyoxovanadates can be considered as a prominent sub-class of POMs and a large range of vanadium oxide clusters exhibiting diverse topologies have been discovered. ${ }^{3}$ Condensation reactions in aqueous vanadate systems result in small building units that give rise to the formation of closed-shell structures. The structures reported by Müller, Zubieta and Christou clearly demonstrate that the linkage of $\left\{\mathrm{VO}_{5}\right\}$ polyhedra can be controlled by small

${ }^{a}$ School of Chemistry \& CRANN, University of Dublin, Trinity College, Dublin 2, Ireland.E-mail: schmittw@tcd.ie; Fax: +3531671 2826; Tel: +35318963495

${ }^{b}$ CNRS, CRPP, UPR 8641, Centre de Recherche Paul Pascal, Equipe "Matériaux Moléculaires Magnétiques", 115 avenue du Dr. Albert Schweitzer, F-33600 Pessac, France

${ }^{c}$ Univ. Bordeaux, CRPP, UPR 8641, F-33600 Pessac, France

${ }^{d}$ School of Biochemistry and Immunology, University of Dublin, Trinity College, Dublin 2, Ireland

$\dagger$ Electronic supplementary information (ESI) available: TGA analysis, infrared spectra and UV-vis spectra; supplementary mass spectra; experimental details regarding cell viability experiments. CCDC reference numbers 820349-820351. For ESI and crystallographic data in CIF or other electronic format see DOI: 10.1039/c2dt11153e

$\downarrow$ Current address; Division of Pulmonary and Critical Care Medicine, Brigham and Women's Hospital, Harvard Medical School, Boston, MA 02115, USA. nucleophilic species, for instance, anions and polar solvent molecules that reside as templates in the centre of the resulting clusters. ${ }^{4-6}$ Depending on the choice of the template, shell-like clusters with different topologies can be synthesised. ${ }^{7}$ The underlying guest-host effect has recently been confirmed by computational studies and resulting polyoxovanadate shells can be classified as cryptands, carcerands or hemi-carcerands depending on the topology of the convex cluster units and the strength of the interaction between the guest and the vanadium oxide shell. ${ }^{8,9}$ The observed assembly concept is not only restricted to purely inorganic polyoxovanadates but can also be applied to functionalised hybrid clusters that are stabilised by organoarsonate and phosphonate ligands. ${ }^{4-6}$ The electronic and geometrical attributes of the latter ligands enable them to be incorporated in vanadate shells and overcome the synthetic restrictions that result from terminal $\mathrm{V}=\mathrm{O}$ bonds. These short terminal bonds that are characterised by stabilising $\mathrm{d} \pi-\mathrm{p} \pi$ contributions, usually protect the cluster cores and hamper their functionalisation. The interest to isolate new functionalised polyoxovanadates is sustained by the need for inorganic clusters of specific size and topologies, functionalised with organic moieties enabling the manipulation of these hybrid materials for improved practical applications. ${ }^{10}$ The functionalization of these compounds may also improve their selectivity and performance as antiviral/cancer drugs allowing specific binding to complementary functionalities of proteins, receptors, or infected tissues. ${ }^{2 d, e}$

We are interested in the concept of hybrid organic-inorganic materials ${ }^{11}$ and we have sought to investigate the self-assembly of vanadate salts and molybdate salts stabilised by 
a)

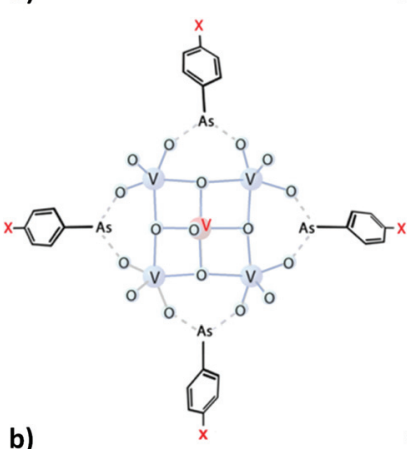

b)

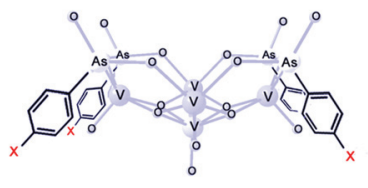

c)

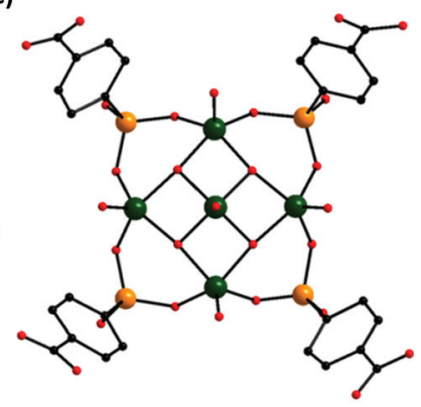

d)

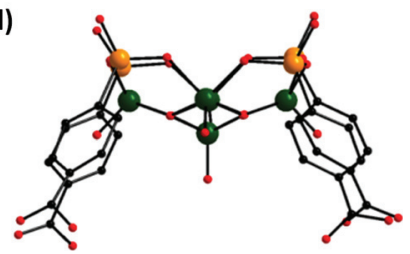

Fig. 1 (a) and (b) Schematic representations of 1-3 whereby $\mathrm{X}=\mathrm{NH}_{2}$, $\mathrm{COO}^{-}$and $\mathrm{OH}$, respectively. (c) Ball-and-stick representation of the anionic $\left[\mathrm{V}_{5} \mathrm{O}_{9}\left(\mathrm{O}_{3} \mathrm{AsC}_{6} \mathrm{H}_{4}-4-\mathrm{COO}\right)_{4}\right]^{9-}$ complex (2) as viewed along the crystallographic $b$-axis. (d) A perspective side on view of $\mathbf{2}$. Hydrogen atoms have been omitted for clarity. Colour code: V green, As orange, $\mathrm{O}$ red, $\mathrm{N}$ blue, $\mathrm{C}$ black.

organoarsonate and organophosphonate ligands in aqueous systems under reducing conditions. ${ }^{12}$ Previously, we reported the crystal structures of four hybrid clusters that contain $\left\{\mathrm{V}_{5} \mathrm{O}_{9}\right\}$ building units. ${ }^{12 a}$

Herein we report an extension of this reaction system and summarise the inter- and intra-molecular assembly of polynuclear vanadate building units in the presence of organoarsonate and organophosphonate ligands (Fig. 1). We demonstrate that the $\left\{\mathrm{V}_{5} \mathrm{O}_{9}\right\}$ building unit can be stabilised by a range of modified organoarsonate ligands whose functionalities direct the assembly of $\left[\mathrm{V}_{5} \mathrm{O}_{9}\left(\mathbf{L}_{\mathbf{1}-3}\right)_{4}\right]^{5-/ 9-}(\mathbf{1 - 3})$ within their crystal structures. The synthetic approach further allows the intramolecular connectivity of these and related subunits and results in arsonatestabilised (hemi)carcerand cages $\left[\mathrm{V}_{12} \mathrm{O}_{14}(\mathrm{OH})_{4}\left(\mathbf{L}_{\mathbf{1}}\right)_{10}\right]^{4-}(\mathbf{4})$ and
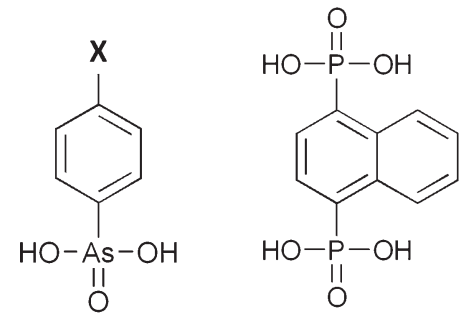

$\mathrm{L}_{1}: X=-\mathrm{NH}_{2}$

$\mathrm{L}_{2}: \mathrm{X}=-\mathrm{COOH}$

$\mathrm{L}_{3}: \mathrm{X}=-\mathrm{OH}$<smiles>O=P(O)(O)c1ccc(P(=O)(O)O)cc1</smiles>

$L_{5}$

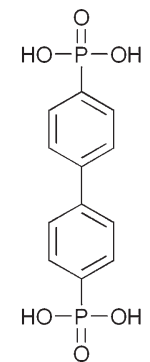

$\mathrm{L}_{6}$

Scheme 1 Functionalising ligands used in this study: 4-aminophenylarsonic acid $\left(\mathbf{L}_{\mathbf{1}}\right)$; 4-carboxylphenylarsonic acid $\left(\mathbf{L}_{2}\right)$; 4-hydroxyphenylarsonic acid $\left(\mathbf{L}_{3}\right)$; (1,4-naphthalene)bisphosphonic acid $\left(\mathbf{L}_{5}\right)$; (1,4benzene)bisphosphonic acid $\left(\mathbf{L}_{\mathbf{4}}\right)$ and (1,1'-biphenyl)-4,4'diylbisphosphonic acid $\left(\mathbf{L}_{\mathbf{6}}\right)$.

phosphonate-stabilised capsules $\left[\mathrm{V}_{10} \mathrm{O}_{18}\left(\mathbf{L}_{\mathbf{4}-\mathbf{6}}\right)_{4}\right]^{10-}(\mathbf{5}-\mathbf{7})$. Our investigations highlight the stability of the latter supramolecular architectures in solution which is often an essential requirement for advanced applications of self-assembled hybrid materials. ${ }^{13}$ We report the crystal structures of three new compounds, mass spectrometry data and the magnetic properties of representative species.

\section{Results and discussion}

\subsection{The intermolecular assembly of the $\left\{\mathrm{V}_{5} \mathrm{O}_{9}\right\}$ secondary building units}

The mixed-valent bowl-shaped, 'calix' $\left\{\mathrm{V}_{5} \mathrm{O}_{9}\right\}$ unit in $\mathbf{1 - 3}$ forms upon partial reduction of sodium metavanadate in an aqueous system at $\mathrm{pH} c a .7$ in the presence of the aromatic ligands $\mathbf{L}_{\mathbf{1}}-\mathbf{L}_{\mathbf{3}}$. The self-assembly process is initiated by the addition of the reducing agent, hydrazine hydrate, which instigates a colour change from bright yellow to a dark green solution. Green crystals of the corresponding compounds form reproducibly in moderate yields after approximately two weeks. Single-crystal X-ray diffraction experiments reveal that the $\mathrm{V}-\mathrm{O}$ core within 1-3 consists of five vanadium atoms that are surrounded by $\mathrm{O}$-donors in a square pyramidal coordination mode (Fig. 1).

The base of the central pyramid in the $\left\{\mathrm{V}_{5} \mathrm{O}_{9}\right\}$ unit shares common edges with its four surrounding $\left\{\mathrm{V}^{\mathrm{IV}} \mathrm{O}_{5}\right\}$ polyhedra to form a convex mixed-valent $\left\{\mathrm{V}^{\mathrm{V}} \mathrm{O}\left(\mu_{3}-\mathrm{O}\right)_{4} \mathrm{~V}^{\mathrm{IV}}{ }_{4} \mathrm{O}_{12}\right\}$ unit. The unit is stabilised by four arsonate ligands. Each of these bridges between two $\mathrm{V}^{\mathrm{IV}}$ atoms in an $\mathrm{O}, \mathrm{O}-$ syn, syn-coordination mode. Bond valence sum analyses confirm the mixed-valent nature of the $\left\{\mathrm{V}_{5} \mathrm{O}_{9}\right\}$ units in $\mathbf{1}-\mathbf{3}(\mathrm{ESI} \dagger)$. Within their core structures $\mathrm{V}^{\mathrm{V}}-$ $\mathrm{O}$ bond distances range from $1.867(1)$ to $1.883(1) \AA$ whilst $\mathrm{V}^{\mathrm{IV}}$ $\mathrm{O}$ bond lengths are expectedly longer and vary between 1.941(1) and 2.001(1) $\AA$.

The organoarsonate-stabilised pentanuclear core carries an overall charge of -5 which is compensated by sodium counterions. All the counter-ions are partially hydrated and display highly distorted octahedral coordination spheres. Within the crystal structure of $\mathbf{2}$, there are four additional sodium counterions that counterbalance the negative charges inferred by the deprotonated secondary carboxylic acid functionalities. In all structures 1-3, the O-donors incorporated in the rim of the calix unit appear to be nucleophilic and provide binding sites for the sodium counterions (Fig. 2). The partially solvated counter-ions further interact with the O-donors of the secondary functionalities (amine, carboxylate and hydroxyl groups) influencing the supramolecular arrangements within the crystal structures.

The packing arrangements of $\mathbf{1}$ and $\mathbf{2}$ result in dense layered assemblies in which the sodium ions are sandwiched between the anionic clusters. The resulting layered lamellar structures are characterised by distinct undulated organic and inorganic areas. The layers extend parallel to the (110) plane in $\mathrm{Na}_{5}[1] \cdot 20.5 \mathrm{H}_{2} \mathrm{O} \cdot 3 \mathrm{DMF}$ and parallel to the (101) plane in $\mathrm{Na}_{9}[2] \cdot 6 \mathrm{DMF} \cdot 24 \mathrm{H}_{2} \mathrm{O}$ (Fig. 2b). The arrangement of the anionic clusters of $\mathbf{3}$ in the packing structure is significantly different and results in an open-framework arrangement in which solvent molecules are contained within channels that run in the direction of the crystallographic $a$-axis. In $\mathrm{Na}_{5}[3] \cdot 5 \mathrm{DMF} \cdot 7 \mathrm{H}_{2} \mathrm{O}$, the hydroxyl 
a)

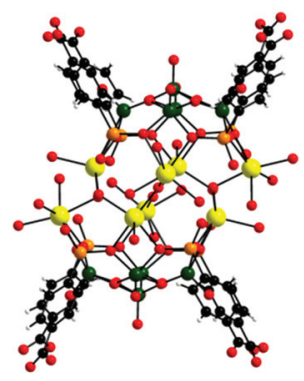

b)

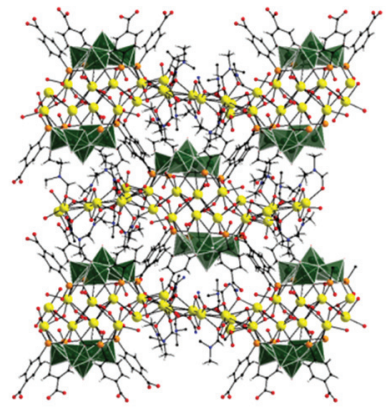

c)

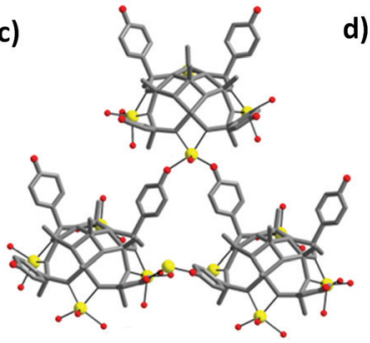

d)

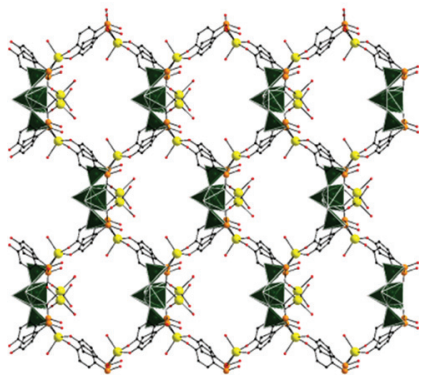

Fig. 2 (a) Ball-and-stick representation of two anionic complexes of 2; sodium counter-ions sandwiched between these two pentanuclear core structures. (b) Crystal structure of $\mathrm{Na}_{9}[2] \cdot 6 \mathrm{DMF} \cdot 24 \mathrm{H}_{2} \mathrm{O}$ when viewed in the direction of the crystallographic $a$-axis with polyhedral representation of the $\mathrm{V}$ coordination environments. (c) A wire-frame representation of the anionic core of $\mathbf{3}$ highlighting the connectivity between the complexes and rim-bound sodium counter-ions. (d) A perspective view of channels in the crystal structure of $\mathrm{Na}_{4} \mathrm{H}[3] \cdot 5 \mathrm{DMF} \cdot 7 \mathrm{H}_{2} \mathrm{O}$ with view in the direction of the crystallographic $a$-axis with polyhedral representation of the $\mathrm{V}$ coordination environments. Solvent molecules located in the channels and hydrogen atoms have been omitted for clarity. Colour code: V green, As orange, Na yellow, O red, C black.

groups of the organic ligands directly interact with the sodium ions binding to the rim of neighbouring oxo-clusters.

Our results demonstrate that para-positioned secondary ligand functionalities do not influence the formation of the calix $\left\{\mathrm{V}_{5} \mathrm{O}_{9}\right\}$ structure. ESI-MS and UV-vis studies confirm the stability of the pentanuclear complexes in DMSO solutions (ESI $\dagger$ ).

2.2 The intramolecular assembly of modified convex calix units through $\left\{\mathrm{O}_{4} \mathrm{~V}^{\mathrm{IV}}(\mathrm{OH})_{2} \mathrm{~V}^{\mathrm{IV}} \mathrm{O}_{4}\right\}$ units to give a molecular $\left[\mathrm{V}_{12} \mathrm{O}_{14}(\mathrm{OH})_{4}\left(\mathrm{~L}_{1}\right)_{10}\right]^{4-}$ cage

Our experiments demonstrate that the central $\left\{\mathrm{V}^{\mathrm{V}} \mathrm{O}_{5}\right\}$ unit can be replaced by an arsonate functionality depending on the $\mathrm{V}^{\mathrm{V}}$ / $\mathrm{V}^{\mathrm{IV}}$ ratio (influenced by the reducing agent) and the $\mathrm{pH}$ of the system (Fig. 3). The mutual replacement of $\left\{\mathrm{V}^{\mathrm{V}} \mathrm{O}_{5}\right\}$ units by arsonate functionalities is the result of their closely related geometries (bond distances and angles). ${ }^{5 b}$ The replacement is observed in $\left[\mathrm{V}_{12} \mathrm{O}_{14}(\mathrm{OH})_{4}\left(\mathbf{L}_{1}\right)_{10}\right]^{4-}(\mathbf{4})$ that forms when the reaction mixtures containing the pentanuclear complex $\mathbf{1}$ are further acidified. The polyoxovanadate cluster $\mathbf{4}$ can be visualised as the linkage of two modified convex calix units via eight arsonate ligands and two $\left\{\mathrm{O}_{4} \mathrm{~V}^{\mathrm{IV}}(\mathrm{OH})_{2} \mathrm{~V}^{\mathrm{IV}} \mathrm{O}_{4}\right\}$ moieties. Closely related compounds with a similar core structure were previously reported. ${ }^{4 a, 5 b}$
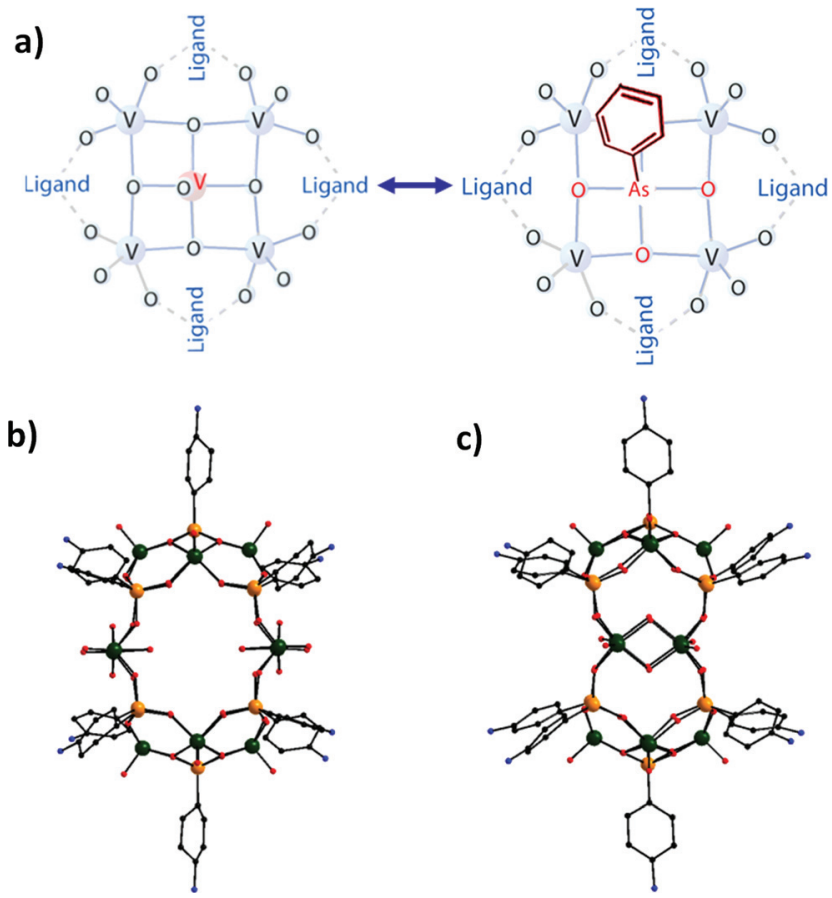

Fig. 3 (a) Formal rearrangement of the $\left\{\mathrm{V}_{5} \mathrm{O}_{9}\right\}$ unit into the capping $\left\{\mathrm{V}_{4} \mathrm{O}_{4} \mathrm{~L}_{1}\right\}$ motif observed in 4. (b) and (c) Different perspective views of the anionic $\left[\mathrm{V}_{12} \mathrm{O}_{14}(\mathrm{OH})_{4}\left(\mathbf{L}_{\mathbf{1}}\right)_{10}\right]^{4-}$ complex (4). Hydrogen atoms have been omitted for clarity. Color code: $\mathrm{V}$ green, As orange, $\mathrm{O}$ red, $\mathrm{N}$ blue, $\mathrm{C}$ black.

\subsection{The intramolecular assembly of the $\left\{\mathrm{V}_{5} \mathrm{O}_{9}\right\}$ secondary} building units through bifunctional phosphonates to give hybrid $\left[\mathrm{V}_{10} \mathrm{O}_{18}\left(\mathrm{~L}_{4-6}\right)_{4}\right]^{10-}$ capsules

Another type of intramolecular connectivity of the $\left\{\mathrm{V}_{5} \mathrm{O}_{9}\right\}$ secondary building units can be achieved through the substitution of the organoarsonate ligands by bifunctional phosphonate ligands $\mathbf{L}_{\mathbf{4}}-\mathbf{L}_{\mathbf{6}}$. This synthetic approach results in hybrid capsules (Fig. 4) with the general formulae $\left[\mathrm{V}_{10} \mathrm{O}_{18}\left(\mathbf{L}_{4-6}\right)_{4}\right]^{10-}(\mathbf{5}-7)$. In these molecular capsules, the $\left\{\mathrm{V}_{5} \mathrm{O}_{9}\right\}$ building units are structurally closely related to the structural motifs in $\mathbf{1 - 3}$. However, the conformational rearrangement of the functional groups of the organic ligands results in the intramolecular linkage of two SBUs whereby four organophosphonate ligands pillar the calix units. Our investigations demonstrate that this assembly process is applicable to a range of bisphosphonates with a variety of aromatic backbones. The $\left[\mathrm{V}_{10} \mathrm{O}_{18}\left(\mathbf{L}_{4}\right)_{4}\right]^{10-}$ capsule (5) incorporates four (1,4-naphthalene)bisphosphonate ligands. The arrangement of the naphthalene rings is such that the aromatic rings point towards an adjacent neighbouring ring in an 'edge-to-face' arrangement. The distances between the 'edge' C-atoms of the naphthalene moieties and the centre of the aromatic rings of adjacent phosphonate ligands vary closely between $3.822(15)$ and 3.976(14) $\AA$.

The dimensions of the central cavity in $\mathbf{5}$ are characterised by a cuboid arrangement of the $8 \mathrm{P}$ atoms $(6.4 \times 5.5 \times 5.5 \AA)$ and an inter-plane distance of $7.9 \AA$ between parallel aligned aromatic rings located opposite to each other. The length of this supramolecular entity of $15.8 \AA$ is defined by an intramolecular $\mathrm{O}-\mathrm{O}$ distance between terminal oxo ligands residing in the 
a)

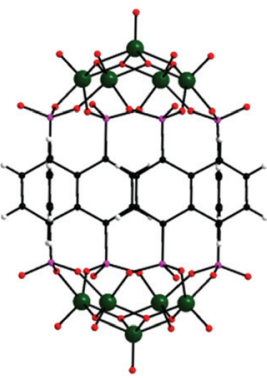

c)

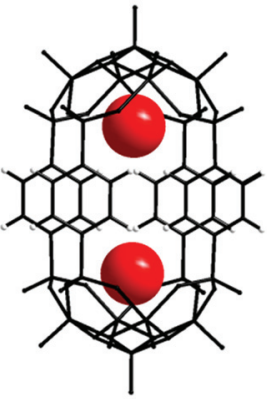

b)

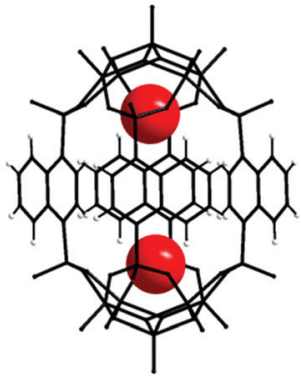

d)

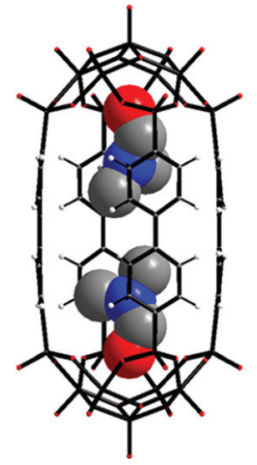

Fig. 4 (a) Ball-and-stick representation of the $\left[\mathrm{V}_{10} \mathrm{O}_{18}\left(\mathbf{L}_{\mathbf{4}}\right)_{4}\right]^{10-}$ capsule (5). (b)-(d) Black wire frame representations of the capsular entities of $\left[\mathrm{V}_{10} \mathrm{O}_{18}\left(\mathbf{L}_{\mathbf{4 - 6}}\right)_{4}\right]^{10-}(\mathbf{5}, \mathbf{6}$ and 7$)$ including their respective encapsulated solvent molecules (space filling representations). Colour code: $\mathrm{V}$ green, $\mathrm{P}$ purple, $\mathrm{O}$ red, $\mathrm{N}$ blue, $\mathrm{C}$ black, hydrogen white.

apical positions. Two symmetry-related water molecules reside within the cavity of this cluster and these water molecules are located at the focal points of the mixed-valent capping motifs at either end of the molecular cage. An almost identical capsular entity can be synthesised with (1,4-benzene)bisphosphonic acid to give $\left[\mathrm{V}_{10} \mathrm{O}_{18}\left(\mathbf{L}_{5}\right)_{4}\right]^{10-}(\mathbf{6})$. The use of the biphenyl ligand derivative $\mathbf{L}_{\mathbf{6}},\left(1,1^{\prime}\right.$-biphenyl)-4,4'diylbisphosphonic acid, results in an elongated molecular capsule that is characterised by a length of $20.1 \AA$. The enlarged cavity in $\left[\mathrm{V}_{10} \mathrm{O}_{18}\left(\mathrm{~L}_{6}\right)_{4}\right]^{10-}(7)$ allows the accommodation of two DMF molecules that point with their hydrophilic O-atoms towards the central $\left\{\mathrm{V}^{\mathrm{V}} \mathrm{O}_{5}\right\}$ units of the polar $\left\{\mathrm{V}_{5} \mathrm{O}_{9}\right\}$ capping motifs. The aromatic hydrocarbon moieties in the crystal structures of $\mathbf{6}$ and $\mathbf{7}$ are disordered over two positions. Bond valence sum analyses of 5-7 clearly confirm the mixed-valent nature and the assigned oxidation states of these species.

ESI-MS analyses (Fig. 5) in negative mode confirm that 5-7 are stable in aqueous solutions. The most intense signals relating to the anionic clusters are observed for the -2 charged species with differing numbers of associated sodium counter-ions. Three relevant isotopic envelopes were observed for $\mathbf{5}$ and were modeled. The most intense signal at $\mathrm{m} / \mathrm{z}=970.6$ corresponds to a -2 charged species with the formula $\mathrm{H}_{8}\left[\left(\mathrm{~V}_{5} \mathrm{O}_{9}\right)_{2}\right.$ $\left.\left(\mathrm{O}_{3} \mathrm{PC}_{10} \mathrm{H}_{6} \mathrm{PO}_{3}\right)_{4}\right]^{2-}$ while the signal at $m / z=981.6$ can be assigned to $\mathrm{NaH}_{7}\left[\left(\mathrm{~V}_{5} \mathrm{O}_{9}\right)_{2}\left(\mathrm{O}_{3} \mathrm{PC}_{10} \mathrm{H}_{6} \mathrm{PO}_{3}\right)_{4}\right]^{2-}$ and the signal at $m / z=992.6$ corresponds to $\mathrm{Na}_{2}\left[\left(\mathrm{~V}_{5} \mathrm{O}_{9}\right)_{2}\left(\mathrm{O}_{3} \mathrm{PC}_{10} \mathrm{H}_{6} \mathrm{PO}_{3}\right)_{4}\right]^{2-}$. Three isotopic envelopes were observed for $\mathbf{6}$ and were modeled. The most intense signal observed at $\mathrm{m} / \mathrm{z}=870.9$ relates to a -2 charged species of $\mathbf{6}$ with eight associated charge balancing protons, $\mathrm{H}_{8}\left[\mathrm{~V}_{10} \mathrm{O}_{18}\left(\mathrm{O}_{3} \mathrm{PC}_{6} \mathrm{H}_{4} \mathrm{PO}_{3}\right)_{4}\right]^{2-}$. A second related signal at $\mathrm{m} / \mathrm{z}=881.6$ can be assigned to the -2 charged cluster of 6

a)
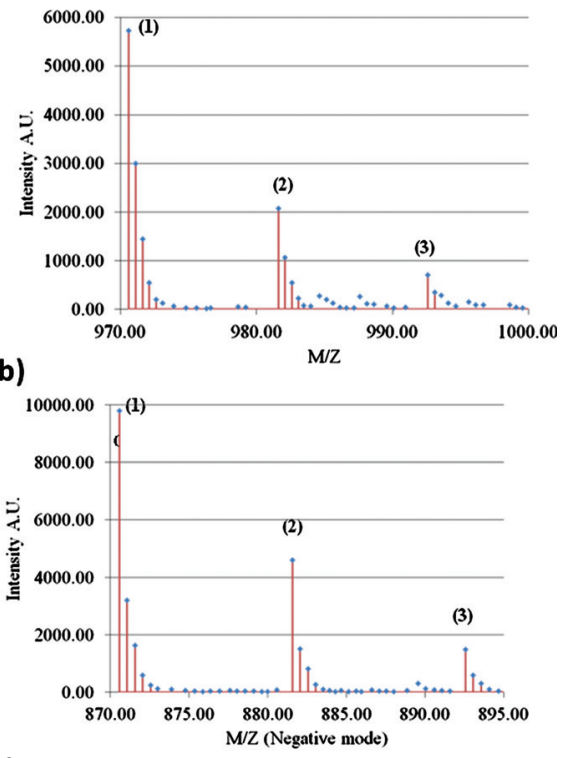

c)

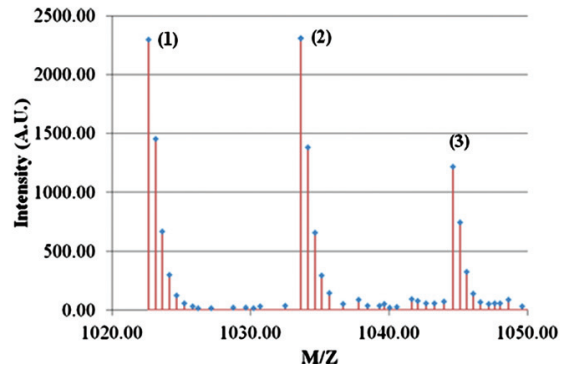

Fig. 5 Negative-mode ESI-MS spectra identifying -2 charged species of the capsular entities of 5, 6 and $\mathbf{7}$ in an aqueous solution. (a) Signal (1) centred at $m / z=970.6$ corresponds to $\mathrm{H}_{8}\left[\left(\mathrm{~V}_{5} \mathrm{O}_{9}\right)_{2}\left(\mathrm{O}_{3} \mathrm{PC}_{10} \mathrm{H}_{6} \mathrm{PO}_{3}\right)_{4}\right]^{2-}$; signal (2) centred at $m / z=981.6$ relates to $\mathrm{NaH}_{7}\left[\left(\mathrm{~V}_{5} \mathrm{O}_{9}\right)_{2}\left(\mathrm{O}_{3} \mathrm{PC}_{10} \mathrm{H}_{6}\right.\right.$ $\left.\left.\mathrm{PO}_{3}\right)_{4}\right]^{2-}$ and signal (3) centred at $m / z=992.6$ corresponds to $\mathrm{Na}_{2}$ $\left[\left(\mathrm{V}_{5} \mathrm{O}_{9}\right)_{2}\left(\mathrm{O}_{3} \mathrm{PC}_{10} \mathrm{H}_{6} \mathrm{PO}_{3}\right)_{4}\right]^{2-}$. (b) Signal (1) centred at $\mathrm{m} / \mathrm{z}=870.6 \mathrm{can}$ be assigned to $\mathrm{H}_{8}\left[\mathrm{~V}_{10} \mathrm{O}_{18}\left(\mathrm{O}_{3} \mathrm{PC}_{6} \mathrm{H}_{4} \mathrm{PO}_{3}\right)_{4}\right]^{2-}$; signal (2) centred at $\mathrm{m} / \mathrm{z}=$ 881.6 corresponds to $\mathrm{NaH}_{7}\left[\mathrm{~V}_{10} \mathrm{O}_{18}\left(\mathrm{O}_{3} \mathrm{PC}_{6} \mathrm{H}_{4} \mathrm{PO}_{3}\right)_{4}\right]^{2-}$ and signal (3) centred at $m / z=892.6$ corresponds to $\mathrm{Na}_{2} \mathrm{H}_{6}\left[\mathrm{~V}_{10} \mathrm{O}_{18}\left(\mathrm{O}_{3} \mathrm{PC}_{6} \mathrm{H}_{4} \mathrm{PO}_{3}\right)_{4}\right]^{2-}$. (c) Signal (1) centred at $m / z=1022.7$ corresponds to $\mathrm{H}_{8}\left[\mathrm{~V}_{10} \mathrm{O}_{18^{-}}\right.$ $\left.\left(\mathrm{O}_{3} \mathrm{PC}_{12} \mathrm{H}_{8} \mathrm{PO}_{3}\right)_{4}\right]^{2-}$; signal (2) centred at $\mathrm{m} / \mathrm{z}=1033.7$ was assigned to $\mathrm{NaH}_{7}\left[\mathrm{~V}_{10} \mathrm{O}_{18}\left(\mathrm{O}_{3} \mathrm{PC}_{12} \mathrm{H}_{8} \mathrm{PO}_{3}\right)_{4}\right]^{2-}$, signal (3) centred at $\mathrm{m} / z=1044.7$ corresponds to $\mathrm{Na}_{2} \mathrm{H}_{6}\left[\mathrm{~V}_{10} \mathrm{O}_{18}\left(\mathrm{O}_{3} \mathrm{PC}_{12} \mathrm{H}_{8} \mathrm{PO}_{3}\right)_{4}\right]^{2-}$. Cone voltage: $30 \mathrm{~V}$. For modeled isotopic envelopes see $\mathrm{ESI} \dagger$.

with a sodium counter-ion and seven charge balancing protons, $\mathrm{NaH}_{7}\left[\mathrm{~V}_{10} \mathrm{O}_{18}\left(\mathrm{O}_{3} \mathrm{PC}_{6} \mathrm{H}_{4} \mathrm{PO}_{3}\right)_{4}\right]^{2-}$. A third related signal at $\mathrm{m} / \mathrm{z}=$ 892.6 corresponds to the -2 charged cluster of 6 with two sodium counter-ions and six associated protons, $\mathrm{Na}_{2} \mathrm{H}_{6}\left[\mathrm{~V}_{10^{-}}\right.$ $\left.\mathrm{O}_{18}\left(\mathrm{O}_{3} \mathrm{PC}_{6} \mathrm{H}_{4} \mathrm{PO}_{3}\right)_{4}\right]^{2-}$. The anionic cluster species of 7 was observed in the mass spectrum as a -2 charged species at $\mathrm{m} / \mathrm{z}=$ 1022.7, 1033.7 and 1044.7. These signals correspond to the fully protonated anionic species, $\mathrm{H}_{8}\left[\mathrm{~V}_{10} \mathrm{O}_{18}\left(\mathrm{O}_{3} \mathrm{PC}_{12} \mathrm{H}_{8} \mathrm{PO}_{3}\right)_{4}\right]^{2-}$ and the sodium salts, $\mathrm{NaH}_{7}\left[\mathrm{~V}_{10} \mathrm{O}_{18}\left(\mathrm{O}_{3} \mathrm{PC}_{12} \mathrm{H}_{8} \mathrm{PO}_{3}\right)_{4}\right]^{2-}$ and $\mathrm{Na}_{2} \mathrm{H}_{6}\left[\mathrm{~V}_{10} \mathrm{O}_{18}\left(\mathrm{O}_{3} \mathrm{PC}_{12} \mathrm{H}_{8} \mathrm{PO}_{3}\right)_{4}\right]^{2-}$. Signals were also observed for -3 and -4 charged species. Furthermore, NMR spectroscopy and UV-vis studies of 5-7 are in agreement with the stability of the molecular structures in aqueous solution (see ESI $\dagger$ ). 
a)

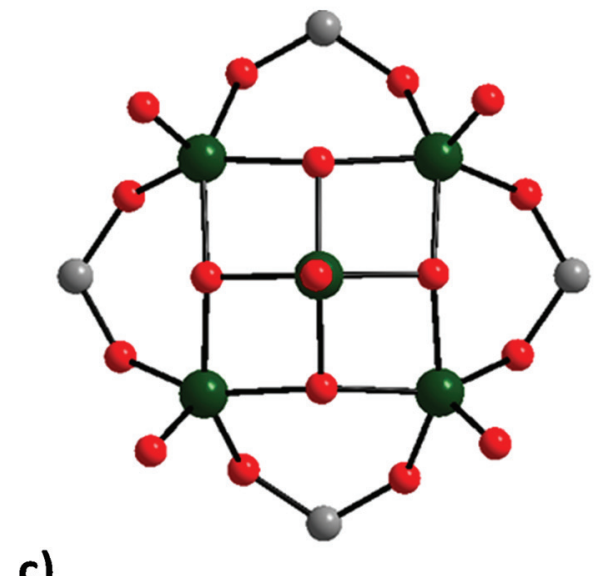

c)

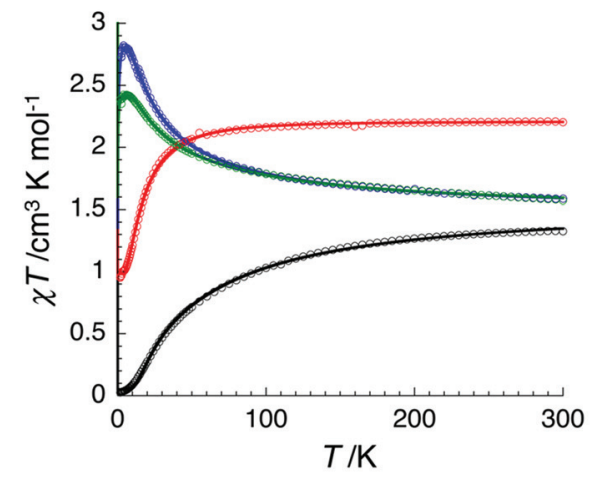

b)

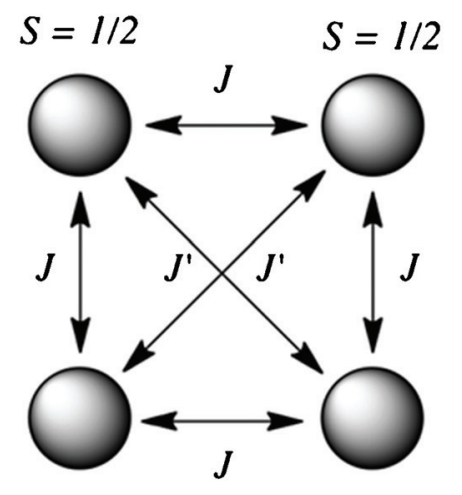

$$
S=1 / 2 \quad S=1 / 2
$$

d)

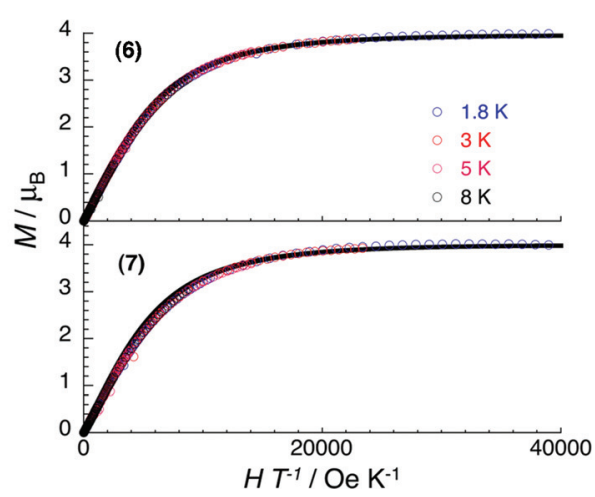

Fig. 6 (a) A representative core of $\left\{\mathrm{V}_{5} \mathrm{O}_{9}\right\}$ found within 1-3 and 5-7. (b) Schematic topology of the magnetic interactions $J$ and $J^{\prime}$ between the $\mathrm{V}^{\mathrm{IV}}$ centres. (c) Temperature dependence of the $\chi T$ product of $\mathbf{1}$ (black), 4 (red), 6 (blue) and 7 (green) at 1000 Oe (with $\chi$ being the molar magnetic susceptibility equal to $M / H$ per $\left\{\mathrm{V}_{5} \mathrm{O}_{9}\right\}$ motif for $\mathbf{1}, \mathbf{6}$ and $\mathbf{7}$ and per $\left\{\mathrm{AsV}_{4} \mathrm{O}_{8}\right\}\left\{\mathrm{V}_{2} \mathrm{O}_{2}\right\}$ motif for 4); Solid lines are the best fit of the experimental data to the Heisenberg model described in the text. (d) Field dependence of the magnetization for $\mathbf{6}$ (top) and 7 (bottom); Solid lines are the best fit of the experimental data to the $S=2$ Brillouin function.

Vanadium-based ligands have reported activities as antitumour, anti-viral and anti-bacterial agents. ${ }^{2 b, d, 14}$ We therefore surmised that $\mathrm{Na}_{8} \mathrm{H}_{2}[6] \cdot 36 \mathrm{H}_{2} \mathrm{O}$ and $\mathrm{Na}_{8} \mathrm{H}_{2}[7] \cdot 2 \mathrm{DMF} \cdot 29 \mathrm{H}_{2} \mathrm{O}$ may have the potential to act as novel anticancer agents. Based on our previous experience, we evaluated the anti-tumour potential of these compounds using the Alamar blue assay for antiproliferative activity in three cancer cell lines that have known resistance to classical chemotherapeutics, namely, the chronic myelogenous leukaemia cancer cell line, K562, the lung carcinoma cancer cell line, A549 and the Burkitt's lymphoma cell line MUTU-I. ${ }^{15}$ Both vanadates were found to have antiproliferative activity against the MUTU-I and the A549 cell lines with approximate $\mathrm{EC}_{50}$ values of $50 \mu \mathrm{M}$ whilst having no effect in the K562 cell line (Fig. S13, ESI†). Such effects could not be attributed to any instability of the capsular entities of these compounds as the starting materials sodium orthovanadate, $p$-arsanilic acid, 1,4-benzenebisphosphonic acid and [1,1'-biphenyl]4,4'-diylbisphosphonic acid and sodium vanadyl were found to have negligible antiproliferative effects at comparative micromolar concentrations (see ESI $\dagger$ ). However, a comparison of the potency of these agents to other effective anticancer agents would place them significantly behind (50-100 $\mu \mathrm{M}$ for
$\mathrm{Na}_{8} \mathrm{H}_{2}[6] \cdot 36 \mathrm{H}_{2} \mathrm{O}$ and $\mathrm{Na}_{8} \mathrm{H}_{2}[7] \cdot 2 \mathrm{DMF} \cdot 29 \mathrm{H}_{2} \mathrm{O}$ compared to 10-40 $\mathrm{nM}$ range of known chemotherapeutic agents). That said, as this data is preliminary, with little information regarding a suspected target based mechanism of action, extensive further investigations are required. Nevertheless, this data strongly suggests that $\mathbf{6}$ and $\mathbf{7}$ may have the ability to enter cancer cells and exert a biological effect. Whether this effect is specific only to certain cancers or cells of malignant origin remains to be investigated. Cellular uptake of these compounds may also support the use of non-toxic derivatives or analogues of $\mathbf{6}$ and 7 as novel drug delivery tools.

\subsection{Magnetism of representative compounds}

The magnetic properties of representative clusters 1, 4, 6 and 7, containing the mixed-valent $\left\{\mathrm{V}^{\mathrm{V}} \mathrm{O}\left(\mu_{3}-\mathrm{O}\right)_{4} \mathrm{~V}^{\mathrm{IV}}{ }_{4} \mathrm{O}_{12}\right\}$ or $\left\{\mathrm{As}\left(\mu_{3^{-}}\right.\right.$ $\left.\mathrm{O})_{4} \mathrm{~V}^{\mathrm{IV}}{ }_{4} \mathrm{O}_{12}\right\}$ units were investigated (Fig. 6).

These investigations reveal that the phosphonate stabilised compounds show significantly different magnetic properties than the structurally related arsonate stabilised compounds. 1, 4, 6 and 7 can be considered to contain squares of $S=1 / 2 \mathrm{~V}^{\mathrm{IV}}$ spin 
centres with a central diamagnetic $\mathrm{V}^{\mathrm{V}}$ or As ion (Fig. 6b). In 1, the square $\left\{\mathrm{V}_{5} \mathrm{O}_{9}\right\}$ unit is stabilised by arsonate ligands $\mathbf{L}_{\mathbf{1}}$ whilst in $\mathbf{6}$ and 7 , related $\left\{\mathrm{V}_{5} \mathrm{O}_{9}\right\}$ squares are assembled into pairs via the bridging aromatic bisphosphonate ligands. In $\mathbf{4}$, the $\left\{\mathrm{AsV}_{4} \mathrm{O}_{8}\right\}$ squares are also paired, but in this case through two paramagnetic $\left\{\mathrm{V}^{\mathrm{IV}}{ }_{2} \mathrm{O}_{2}\right\}$ dinuclear units. The interactions between the two squares in $\mathbf{6}$ and $\mathbf{7}$ or between the squares and dinuclear moieties in $\mathbf{4}$ are likely to be weak and the main magnetic interactions should prevail within the tetranuclear and dinuclear units.

At room temperature, the $\chi T$ products reveal values of 1.33 , $2.20,1.58$ and $1.57 \mathrm{~cm}^{3} \mathrm{~K} \mathrm{~mol}^{-1}$ for $\mathbf{1}, \mathbf{4}, \mathbf{6}$ and 7, respectively (Fig. 6c). The measured values are in good agreement with the expected values $\left(1.50\right.$ or $\left.2.25 \mathrm{~cm}^{3} \mathrm{~K} \mathrm{~mol}^{-1}\right)$ for four or six $\mathrm{V}^{\mathrm{IV}}$ metal ions $\left(S=1 / 2, g=2.0: C=0.375 \mathrm{~cm}^{3} \mathrm{~K} \mathrm{~mol}^{-1}\right)$. The arsonate-stabilised cluster 1 shows a significantly different magnetic behaviour than 6 and 7. Decreasing the temperature, the $\chi T$ product of 1 steadily decreases to vanish almost completely below $8 \mathrm{~K}$ to give a residual value of $0.02 \mathrm{~cm}^{3} \mathrm{~K} \mathrm{~mol}^{-1}$ at $1.8 \mathrm{~K}$. This behaviour highlights the presence of antiferromagnetic interactions between the $\mathrm{V}^{\mathrm{IV}}$ centres resulting in a singlet ground state $\left(S_{\mathrm{T}}=0\right)$. The magnetic interactions between the $\mathrm{V}$ ions were modeled using a tetranuclear $S=1 / 2$ Heisenberg model (with $\boldsymbol{H}=-2 J\left(\boldsymbol{S}_{1} \boldsymbol{S}_{2}+\boldsymbol{S}_{2} \boldsymbol{S}_{3}+\boldsymbol{S}_{3} \boldsymbol{S}_{4}+\boldsymbol{S}_{1} \boldsymbol{S}_{4}\right)$ assuming an equal magnetic exchange, $J$, between the four $S=1 / 2$ metal ions. However, to obtain a satisfactory fit of the temperature dependence of the $\chi T$ product, an additional second coupling constant, $J^{\prime}$, allowing coupling between the four $\mathrm{V}^{\mathrm{IV}} S=1 / 2$ centres through the central $\mathrm{V}^{\mathrm{V}}$ diamagnetic centre, had to be introduced (Fig. 6b, with $\boldsymbol{H}=-2 J\left(\boldsymbol{S}_{1} \boldsymbol{S}_{2}+\boldsymbol{S}_{2} \boldsymbol{S}_{3}+\boldsymbol{S}_{3} \boldsymbol{S}_{4}+\boldsymbol{S}_{1} \boldsymbol{S}_{4}\right)-2 J^{\prime}\left(\boldsymbol{S}_{1} \boldsymbol{S}_{3}+\right.$ $\left.S_{2} S_{4}\right)$ ). It was found that the two proposed exchange pathways are of similar magnitude and the best fit between the theoretical and experimental data was obtained with $J / k_{\mathrm{B}}=J^{\prime} / k_{\mathrm{B}}=-27.8(5)$ $\mathrm{K}$ and $g=1.99(2)$.

Decreasing the temperature, the $\chi T$ products of $\mathbf{6}$ and 7 steadily increase to maxima at 5.0 and $6.1 \mathrm{~K}$ of 2.8 and $2.4 \mathrm{~cm}^{3} \mathrm{~K}$ $\mathrm{mol}^{-1}$, respectively, demonstrating the presence of dominating ferromagnetic interactions within the $\left\{\mathrm{V}^{\mathrm{IV}}{ }_{4} \mathrm{~V}^{\mathrm{V}}\right\}$ cores and thus stabilising an $S_{\mathrm{T}}=2$ spin ground state for the pentanuclear unit. At lower temperature, the $\chi T$ products decrease slightly to 2.7 and $2.3 \mathrm{~cm}^{3} \mathrm{~K} \mathrm{~mol}^{-1}$ at $1.8 \mathrm{~K}$ for 6 and 7 indicating the presence of very weak inter-complex antiferromagnetic interactions. The model applied to $\mathbf{1}$ was again used to fit the data of $\mathbf{6}$ and $\mathbf{7}$ but in order to reproduce the data below $6 \mathrm{~K}$, weak inter-complex interactions, $J_{\mathrm{AF}}$, have been introduced in the model in the frame of the mean-field approximation. ${ }^{16}$ The best set of parameters obtained are $J / k_{\mathrm{B}}=+32.4(2) \mathrm{K}, J^{\prime} / k_{\mathrm{B}}=-12.4(1) \mathrm{K}$ and $z J_{\mathrm{AF}} / k_{\mathrm{B}}$ $=-0.04(1) \mathrm{K}$ for 6 and are $J / k_{\mathrm{B}}=+37(4) \mathrm{K}, J^{\prime} / k_{\mathrm{B}}=-19(3) \mathrm{K}$ and $z J_{\mathrm{AF}} / k_{\mathrm{B}}=-0.01(1) \mathrm{K}$ for 7 ( $g=1.98(2)$ for both systems). The sign of the exchange parameter $J$ implies the $S_{\mathrm{T}}=2$ ground state of the $\left\{\mathrm{V}_{5} \mathrm{O}_{9}\right\}$ units even if the $J^{\prime}$ values remain antiferromagnetic by nature. This $S_{\mathrm{T}}=2$ ground state is further confirmed by the $M v s$. $H$ data that are very well fitted to an $S=$ 2 Brillouin function (Fig. 6d).

Decreasing the temperature, the $\chi T$ product of $\mathbf{4}$ steadily decreases to reach a plateau below $6 \mathrm{~K}$ of $c a .1 .0 \mathrm{~cm}^{3} \mathrm{~K} \mathrm{~mol}^{-1}$ thus suggesting that this complex or at least a part of this complex has a triplet ground state $\left(S_{\mathrm{T}}=1\right)$. This observation suggests dominant antiferromagnetic interactions as observed in

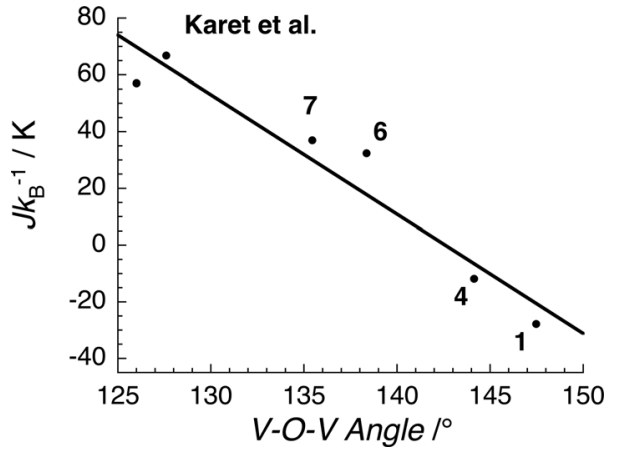

Fig. $7 J / k_{\mathrm{B}} v s$. average $\mathrm{V}^{\mathrm{IV}}-\mathrm{O}-\mathrm{V}^{\mathrm{IV}}$ angle in the $\left\{\mathrm{V}_{4} \mathrm{O}_{8}\right\}$ unit in $\mathbf{1 , 4} \mathbf{4}$, 7 and in compounds reported by Karet et al. ${ }^{6 b}$

the corresponding arsonate-stabilised complex $\mathbf{1}$ but with a residual paramagnetic contribution likely coming from ferromagnetically coupled $\left\{\mathrm{V}^{\mathrm{IV}}{ }_{2}\right\}$ units as the $\left\{\mathrm{V}_{4} \mathrm{O}_{8}\right\}$ parts should display a singlet (like for $\mathbf{1}$ ) or quintet (like for $\mathbf{6}$ and 7) ground state due to antiferromagnetic or ferromagnetic intra-complex interactions respectively. In order to probe this assumption, the magnetic data were fitted to a Heisenberg model that considers the $\left\{\mathrm{V}^{\mathrm{IV}}{ }_{4}\right\}$ core as in the previous complexes and the $\left\{\mathrm{V}^{\mathrm{IV}}{ }_{2}\right\}$ dinuclear unit as an isolated $S=1 / 2$ dinuclear moiety: $\boldsymbol{H}=$ $-2 J_{\mathrm{d}}\left\{\boldsymbol{S}_{5} \boldsymbol{S}_{\mathbf{6}}\right\}$. The theoretical susceptibility is thus the sum of the susceptibilities for the tetranuclear and dinuclear units. The best set of parameters obtained using this model are $J / k_{\mathrm{B}}=-11.9(2)$ $\mathrm{K} ; J^{\prime} / k_{\mathrm{B}} \approx 0.0(5) \mathrm{K} ; J_{\mathrm{d}} / k_{\mathrm{B}}=+48(10) \mathrm{K}$ and $g=1.98(2)$ (red solid line, Fig. 6c). The sign of the magnetic interaction, $J$, implies that the $\left\{\mathrm{V}^{\mathrm{IV}}{ }_{4}\right\}$ unit in $\mathbf{4}$ possesses an $S_{\mathrm{T}}=0$ spin ground state like in 1. Our model also indicates that the $J^{\prime}$ interactions are close to zero suggesting that the replacement of $\mathrm{V}^{\mathrm{V}}$ by arsonate ligands suppresses this exchange pathway. The $S_{\mathrm{T}}=1 \mathrm{spin}$ ground state per dinuclear unit in $\mathbf{4}$ is also supported by the good fit of the $M v s$. $H / T$ data obtained using an $S=1$ Brillouin function (Fig. S14, ESI广†; with $g=1.96(2)$ ).

These results correlate with significant geometrical changes of the $\{\mathrm{O} / \mathrm{OPO}\}$ or $\{\mathrm{O} / \mathrm{OAsO}\}$ bridges that mediate the magnetic exchange between paramagnetic $\mathrm{V}^{\mathrm{IV}}$ spin carriers. These distortions are clearly associated with a substitution of arsonate ligands by phosphonate ligands. The $\mathrm{V}-\mathrm{O}-\mathrm{V}$ angle is an appropriate parameter that characterises the bonding geometry of the $\left\{\mathrm{V}_{5} \mathrm{O}_{9}\right\}$ unit and the degree of overlap of the magnetic orbitals that influence the magnetic interactions. The $\mathrm{V}-\mathrm{O}-\mathrm{V}$ angles in the arsonate stabilised complex 1 vary between 144.3 and $150.1^{\circ}$ whilst the corresponding angles in the phosphonate systems $\mathbf{6}$ and 7 are 138.3 and $135.1^{\circ}$. These angles and associated $J$ values are in good agreement with those reported by Karet et $a l .{ }^{6 b}$ who investigated a related vanadate system. These and our results indicate a quasi-linear relationship between the $\mathrm{V}-\mathrm{O}-$ $\mathrm{V} \alpha$ angle and the magnitude of the exchange parameter $J: J / k_{\mathrm{B}}$ $=600.1-4.21 \alpha$ (Fig. 7). The magnetic properties of 4 further support this experimental observation. As predicted by the above relation, the $\mathrm{V}-\mathrm{O}-\mathrm{V}$ angles of $143.0-145.3^{\circ}$ in 4 promote antiferromagnetic interactions between the spin centres; this is in agreement with the estimation obtained from the fitting of the $\chi T$ vs. $T$ data $\left(J / k_{\mathrm{B}}=-11.9(2) \mathrm{K}\right)$. 


\section{Reduction of Vanadates(V) in the Presence of Organoarsonates and -Phosphonates}

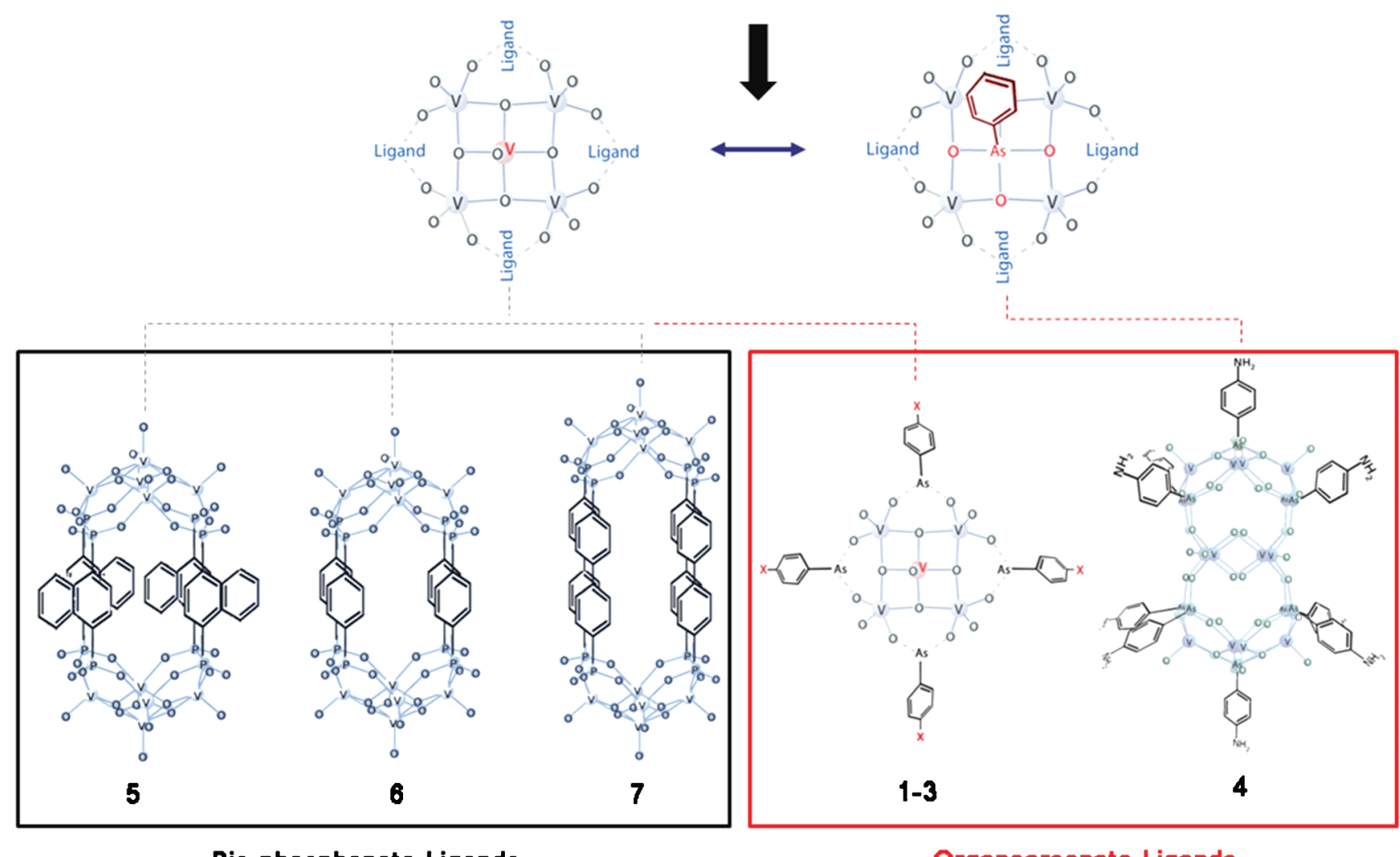

Bis-phosphonate Ligands

Organoarsonate Ligands

Fig. 8 Assembly of functionalised polyoxovanadate clusters in the presence of organophosphonate and organoarsonate ligands $\left(\mathrm{X}=\mathrm{NH}_{2}\right.$, $\mathrm{OH}$ or $\mathrm{COO}^{-}$).

Table 1 Crystal data and structure refinement

\begin{tabular}{|c|c|c|c|}
\hline & $\mathrm{Na}_{9}[2] \cdot 6 \mathrm{DMF} \cdot 24 \mathrm{H}_{2} \mathrm{O}$ & $\mathrm{Na}_{4} \mathrm{H}[3] \cdot 6 \mathrm{H}_{2} \mathrm{O}$ & $\mathrm{Na}_{10}[\mathbf{5}] \cdot 51.5 \mathrm{H}_{2} \mathrm{O}$ \\
\hline Formula & $\mathrm{C}_{46} \mathrm{H}_{106} \mathrm{As}_{4} \mathrm{~N}_{6} \mathrm{Na}_{9} \mathrm{O}_{59} \mathrm{~V}_{5}$ & $\mathrm{C}_{48} \mathrm{H}_{66} \mathrm{As}_{8} \mathrm{Na}_{8} \mathrm{O}_{62} \mathrm{~V}_{10}$ & $\mathrm{C}_{40} \mathrm{H}_{127} \mathrm{Na}_{10} \mathrm{O}_{93 \cdot 5} \mathrm{P}_{8} \mathrm{~V}_{10}$ \\
\hline$M_{\mathrm{r}}$ & 2448.65 & 2927.69 & 3091.48 \\
\hline Crystal system & Monoclinic & Orthorhombic & Triclinic \\
\hline$a / \AA ̊$ & $18.026(4)$ & $14.512(7)$ & $14.9555(15)$ \\
\hline$b / \AA$ & $23.202(5)$ & $22.664(12)$ & $15.1182(15)$ \\
\hline$c / \AA ̊$ & $26.312(9)$ & $13.699(8)$ & $17.0608(17)$ \\
\hline$\alpha /^{\circ}$ & 90.00 & 90.00 & $109.381(2)$ \\
\hline$\beta /^{\circ}$ & $121.29(2)$ & 90.00 & $106.595(2)$ \\
\hline$\gamma /{ }^{\circ}$ & 90.00 & 90.00 & $107.314(2)$ \\
\hline$V / \AA^{3}$ & $9404(4)$ & $4506(4)$ & $3141.3(5)$ \\
\hline$T / \mathrm{K}$ & $150(2)$ & $150(2)$ & $150(2)$ \\
\hline Space group & $P 2_{1} / c$ & Pnn2 & $P \overline{1}$ \\
\hline$Z$ & 4 & 1 & 1 \\
\hline GOF & 1.006 & 1.063 & 1.016 \\
\hline Flack parameter & - & $0.44(3)$ & - \\
\hline Total data & 16358 & 7704 & 11020 \\
\hline Unique data & 13866 & 6549 & 8149 \\
\hline$R_{\text {int }}$ & 0.0505 & 0.0548 & 0.0611 \\
\hline$R_{1}^{a}(I>2 \sigma(I))$ & 0.0929 & 0.1024 & 0.1101 \\
\hline $\mathrm{w} R_{2}{ }^{a}$ (all data) & 0.3785 & 0.2863 & 0.3064 \\
\hline
\end{tabular}




\section{Summary}

In summary, a $\left\{\mathrm{V}_{5} \mathrm{O}_{9}\right\}$ building unit can be exploited for selfassembly processes depending on the nature of the stabilising ligands (Fig. 8). The $\left\{\mathrm{V}_{5} \mathrm{O}_{9}\right\}$ unit allows the incorporation of aromatic organoarsonate ligands with a variety of different secondary functional groups. The complexes 1-3 are stable in solution and the ligand functionalities influence the 3-D packing arrangements of the complexes within their crystal structures. Modified $\left\{\mathrm{L}_{\mathbf{1}} \mathrm{V}_{4} \mathrm{O}_{4}\right\}$ building units can be assembled through purely inorganic $\left\{\mathrm{O}_{4} \mathrm{~V}^{\mathrm{IV}}(\mathrm{OH})_{2} \mathrm{~V}^{\mathrm{IV}} \mathrm{O}_{4}\right\}$ moieties to give 4. Intramolecular connectivity of two $\left\{\mathrm{V}_{5} \mathrm{O}_{9}\right\}$ building units through bisphosphonate ligands results in stable hybrid capsules 5, 6 and 7 whose dimensions and inner cavities can be tailored by the nature and extent of the aromatic ligand used. ESI-MS and other supplemental analyses confirm that these supramolecular assemblies are stable in aqueous systems. Cell-viability studies using MUTU-I and the A549 cell lines with respect to $\mathrm{Na}_{8} \mathrm{H}_{2}[6] \cdot 36 \mathrm{H}_{2} \mathrm{O}$ and $\mathrm{Na}_{8} \mathrm{H}_{2}[7] \cdot 2 \mathrm{DMF} \cdot 29 \mathrm{H}_{2} \mathrm{O}$ give $\mathrm{EC}_{50}$ values of $c a .50 \mu \mathrm{M}$ suggesting that these compounds are moderately chemo-toxic. Investigations of the magnetic properties revealed antiferromagnetic interactions between the $\mathrm{V}^{\mathrm{IV}}$ spin-centres within the arsonate stabilised complexes $\mathbf{1}$ and $\mathbf{4}$. In contrast, at low-temperature, the magnetic properties of the $\left\{\mathrm{V}_{5} \mathrm{O}_{9}\right\}$ units in 6 and 7 are characterised by predominantly ferromagnetic interactions leading to an $S_{\mathrm{T}}=2$ spin ground state per subunit.

\section{Experimental}

All reagents were purchased from Sigma Aldrich and ABCR and used without further purification. The ligands $\mathbf{L}_{2}, \mathbf{L}_{\mathbf{4}}, \mathbf{L}_{\mathbf{5}}$ and $\mathbf{L}_{\mathbf{6}}$ were prepared according to a literature method. ${ }^{17,18}$

Single-crystal analyses were performed at $150 \mathrm{~K}$ with a Bruker SMART APEX CCD diffractometer or a Rigaku Saturn 724 CCD diffractometer using graphite-monochromated Mo-K $\alpha$ radiation $(\lambda=0.71073 \AA)$. Full spheres of data was obtained using the $\omega$ scan method. Data were collected, processed, and corrected for Lorentz and polarization effects using Crystalclear, SMART, SAINT-NT and software. ${ }^{19}$ The structures were solved using direct methods and refined with the SHELXTL program package. ${ }^{20}$ Elemental and thermogravimetric analyses were used to derive the number of unresolved solvent molecules in the compounds. The structure of $\mathrm{Na}_{4} \mathrm{H}[3] \cdot 5 \mathrm{DMF} \cdot 7 \mathrm{H}_{2} \mathrm{O}$ contains highly disordered solvent molecules and we applied the programme SQUEEZE. ${ }^{21}$ The given formula was assigned based on the $\mathrm{CHN}$ analysis and crystallographic data. The examined crystal of $\mathrm{Na}_{4} \mathrm{H}[3] \cdot 5 \mathrm{DMF} \cdot 7 \mathrm{H}_{2} \mathrm{O}$ was a racemic twin, as suggested by the Flack parameter of $0.44(3)$. The crystallographic data for $\mathrm{Na}_{9}[2] \cdot 6 \mathrm{DMF} \cdot 24 \mathrm{H}_{2} \mathrm{O}, \mathrm{Na}{ }_{4} \mathrm{H}[3] \cdot 5 \mathrm{DMF} \cdot 7 \mathrm{H}_{2} \mathrm{O}$ and $\mathrm{Na}_{10}[\mathbf{5}] \cdot 51.5 \mathrm{H}_{2} \mathrm{O}$ are given in Table 1 . The structures and syntheses of $\mathrm{Na}_{5}[\mathbf{1}] \cdot 20.5 \mathrm{H}_{2} \mathrm{O} \cdot 3 \mathrm{DMF}, \mathrm{Na}_{4}[4] \cdot 1.5 \mathrm{DMF} \cdot 12.25 \mathrm{H}_{2} \mathrm{O}$, $\mathrm{Na}_{8} \mathrm{H}_{2}[6] \cdot 36 \mathrm{H}_{2} \mathrm{O}$ and $\mathrm{Na}_{8} \mathrm{H}_{2}[7] \cdot 2 \mathrm{DMF} \cdot 29 \mathrm{H}_{2} \mathrm{O}$ were previously reported by us. ${ }^{12 a}$

\section{Synthesis of $\mathrm{Na}_{9}[2] \cdot 6 \mathrm{DMF} \cdot 24 \mathrm{H}_{2} \mathrm{O}$}

A mixture of $\mathrm{NaVO}_{3}(0.190 \mathrm{~g}, 1.53 \mathrm{mmol}), \mathrm{NaN}_{3}(0.250 \mathrm{~g}$, $3.85 \mathrm{mmol})$, (4-carboxyphenyl)arsonic acid (0.492 g,
$2.0 \mathrm{mmol}), \mathrm{H}_{2} \mathrm{O}(20 \mathrm{~mL})$ and $\mathrm{DMF}(10 \mathrm{~mL})$ was vigorously stirred at $70{ }^{\circ} \mathrm{C}$ until a clear solution formed. $\mathrm{N}_{2} \mathrm{H}_{4} \cdot \mathrm{H}_{2} \mathrm{O}$ $(0.045 \mathrm{~mL}, 0.927 \mathrm{mmol})$ was added and $32 \%$ aq. $\mathrm{HCl}$ was used to re-adjust the $\mathrm{pH}$ of the dark green solution to neutral $\mathrm{pH}$. The solution was filtered hot, allowed to cool to room temperature and filtered again after one day. Dark green crystals were formed after two weeks. Yield: $12 \%$, based on $\mathrm{NaVO}_{3}$. FTIR $\left(\mathrm{cm}^{-1}\right)$ $\tilde{v}_{\text {max }}$ : 3476(br), 2939(w), 1652(vs), 1583(m), 1491(m), 1476(w), 1389(s), 1281(m), 1268(m), 1176(w), 1095(vs), 998(s), 996(sh), 833(s), 792(s), 662(m), 635(m), 617(s). UV-vis (in DMSO): $\lambda / \mathrm{nm}=604,714$. CHN analysis on dried sample: calc. for $\mathrm{C}_{46-}$ $\mathrm{H}_{88} \mathrm{~N}_{6} \mathrm{O}_{50} \mathrm{Na}_{9} \mathrm{~V}_{5} \mathrm{As}_{4}$ (corresponding to the crystallographically determined formula and a loss of $9 \mathrm{H}_{2} \mathrm{O}$ ): $\mathrm{C} 24.16, \mathrm{H} \mathrm{3.88}, \mathrm{N}$ 3.68; found: C 24.20, H 4.26, N 3.91\%.

\section{Synthesis of $\mathrm{Na}_{4} \mathrm{H}[3] \cdot 5 \mathrm{DMF} \cdot 7 \mathrm{H}_{2} \mathrm{O}$}

A very similar synthesis to $\mathrm{Na}_{9}[2] \cdot 6 \mathrm{DMF} \cdot 24 \mathrm{H}_{2} \mathrm{O}$ was used, however, (4-hydroxyl)arsonic acid (0.436 g, $2 \mathrm{mmol})$ was used in place of (4-carboxyphenyl)arsonic acid. Yield: 19\%, based on $\mathrm{NaVO}_{3}$. FTIR $\left(\mathrm{cm}^{-1}\right) \tilde{v}_{\text {max }}$ : 3443(br), 2940(w), 1649(vs), 1584 (s), 1491(s), 1473(m), 1389(s), 1278(s), 1176(w), 1096(s), 1002 (sh), 987(s), 832(sh), 792(vs). UV-vis (in DMSO): $\lambda / \mathrm{nm}=605$, 704. MS ( $m / z$, ES in DMSO): found: $1266.5\left(\mathrm{M}^{-}-5 \mathrm{Na}^{+}+\right.$ $4 \mathrm{H}^{+}: \mathrm{C}_{24} \mathrm{H}_{24} \mathrm{O}_{25} \mathrm{~V}_{5} \mathrm{As}_{4}$; calc.: 1266.5). $\mathrm{CHN}$ analysis: calc. for $\mathrm{C}_{39} \mathrm{H}_{70} \mathrm{~N}_{5} \mathrm{O}_{37} \mathrm{Na}_{4} \mathrm{~V}_{5} \mathrm{As}_{4}$ (corresponding to the crystallographically determined formula and an additional five DMF molecules and one water molecule): C 25.34, H 3.82, N 3.79\%; found: C 25.04, H 3.45, N 4.20\%.

\section{Synthesis of $\mathrm{Na}_{10}[5] \cdot 51.5 \mathrm{H}_{2} \mathrm{O}$}

(1,4-Naphthalene)bisphosphonic acid (0.247 $\mathrm{g}, 0.86 \mathrm{mmol})$, $\mathrm{Na}_{3} \mathrm{VO}_{4}(0.28 \mathrm{~g}, 1.50 \mathrm{mmol}), \mathrm{NaN}_{3}(0.25 \mathrm{~g}, 3.80 \mathrm{mmol}), \mathrm{H}_{2} \mathrm{O}$ $(15 \mathrm{~mL}), \mathrm{DMF}(15 \mathrm{~mL})$ and triethylamine $(0.25 \mathrm{~mL}$, $1.79 \mathrm{mmol}$ ) were heated at $70{ }^{\circ} \mathrm{C}$ for $15 \mathrm{~min} .32 \%$ aq. $\mathrm{HCl}$ was used to adjust the $\mathrm{pH}$ of the yellow solution to $c a . \mathrm{pH} 6.5$. $\mathrm{N}_{2} \mathrm{H}_{4} \cdot \mathrm{H}_{2} \mathrm{O}(0.045 \mathrm{~mL}, 0.927 \mathrm{mmol})$ was added and aqueous conc. $\mathrm{HCl}(32 \%)$ was subsequently added again to re-adjust the $\mathrm{pH}$ of the light green reaction mixture to $\mathrm{pH}$ 7.50. The solution was stirred for $1 \mathrm{~h}$. Dark green cube shaped crystals were observed after several days. Yield $30 \%$, based on $\mathrm{Na}_{3} \mathrm{VO}_{4}$. FTIR $\left(\mathrm{cm}^{-1}\right) \tilde{v}_{\max }:$ 3397(br), 3241(sh), 1645(s), 1510(m), 1453(w), 1384(w), 1209(w), 1119(sh), 1033(sh), 962(s), 889(sh), 765(m). $\mathrm{CHN}$ analysis: calc. for $\mathrm{C}_{40} \mathrm{H}_{78} \mathrm{Na}_{10} \mathrm{O}_{69} \mathrm{P}_{8} \mathrm{~V}_{10}$ (corresponding to the crystallographically determined formula and a loss of 24.5 $\mathrm{H}_{2} \mathrm{O}$ ): C 18.31, H 3.15\%; found: C 18.03, H 2.87\%. UV-vis (in DMSO): $\lambda / \mathrm{nm}=618,758$. MS ( $\mathrm{m} / z$, ES in DMSO): found: 970.6 $\left(\mathrm{M}^{2-}-8 \mathrm{Na}^{+}+6 \mathrm{H}^{+}: \mathrm{C}_{40} \mathrm{H}_{32} \mathrm{O}_{42} \mathrm{P}_{8} \mathrm{~V}_{10}\right.$; calc.: 970.6); $981.6\left(\mathrm{M}^{2-}-7 \mathrm{Na}^{+}+5 \mathrm{H}^{+}: \mathrm{C}_{40} \mathrm{H}_{31} \mathrm{O}_{42} \mathrm{NaP}_{8} \mathrm{~V}_{10}\right.$ calc.: 981.6); $992.6\left(\mathrm{M}^{2-}-6 \mathrm{Na}^{+}+4 \mathrm{H}^{+}: \mathrm{C}_{40} \mathrm{H}_{30} \mathrm{O}_{42} \mathrm{Na}_{2} \mathrm{P}_{8} \mathrm{~V}_{10}\right.$; calc.: 992.6).

\section{Acknowledgements}

This work was supported by the Science Foundation Ireland (SFI) for financial support (Grants 06/RFP/CHE173 and 08/ IN.1/I2047). Financial support from the CNRS, the University of Bordeaux, The Region Aquitaine and the GIS Advanced 
Materials in Aquitaine (COMET Project) is also gratefully acknowledged.

\section{Notes and references}

1 (a) A. Dolbecq, E. Dumas, C. R. Mayer and P. Mialane, Chem. Rev., 2010, 110, 6009; (b) A. Proust, R. Thouvenot and P. Gouzerh, Chem. Commun., 2008, 1837; (c) P. Gouzerh and A. Proust, Chem. Rev., 1998, 98, 77; (d) D-L. Long and L. Cronin, Chem.-Eur. J., 2006, 12, 3698; (e) Y. Du, A. L. Rheingold and E. A. Maatta, J. Am. Chem. Soc., 1992, 114, 345; (f) Y. Wei, B. Xu, C. L. Barnes and Z. Peng, J. Am. Chem. Soc., 2001, 123, 4083; $(g)$ R. J. Errington, C. Lax, D. G. Richards, W. Clegg and K. A. Fraser, in Polyoxometalates: From Platonic Solids to Anti-Retroviral Activity, ed. M. T. Pope and A. Müller, Kluwer, Dordrecht, 1994; (h) B. J. S. Johnson, S. A. Geers, W. W. Brennessel, V. G. Young and A. Stein, Dalton Trans., 2003, 4678; (i) J. Spandl, I. Brüdgam and H. Hartl, Angew. Chem., Int. Ed., 2001, 40, 4018; (j) Z. Peng, Angew. Chem., Int. Ed., 2004, 43, 930; (k) Y.-F. Song, D.-L. Long, S. E. Kelly and L. Cronin, Inorg. Chem., 2008, 47, 9137.

2 (a) I. A. Weinstock, E. M. G. Barbuzzi, M. W. Wemple, J. F. Cowan, S. Reiner, D. M. Sonnen, R. A. Heintz, J. S. Bond and C. L. Hill, Nature, 2001, 414, 191; (b) T. J. Yamase, Mater. Chem., 2005, 15, 4473; (c) D. E. Katsoulis, Chem. Rev., 1998, 98, 359; (d) B. Hasenknopf, Front. Biosci., 2005, 10, 275; (e) T. Yamase, Chem. Rev., 1998, 98, 307; (f) F. Ma, S. Liu, D. Liang, G. Ren, C. Zhang, F. Wei and Z. Su, Eur. J. Inorg. Chem., 2010, 3756; (g) F. Odobel, M. Séverac, Y. Pellegrin, E. Blart, C. Fosse, C. Cannizzo, C. R. Mayer, K. J. Elliott and A. Harriman, Chem.-Eur. J., 2009, 15, 3130.

3 (a) V. W. Day, W. G. Klemperer and A. Yagasaki, Chem. Lett., 1990, 1267; (b) V. W. Day, W. G. Klemperer and O. M. Yaghi, J. Am. Chem. Soc., 1989, 111, 4518; (c) M. I. Khan, S. Ayesh, R. J. Doedens, M. Yu and C. J. O'Connor, Chem. Commun., 2005, 4658; (d) H. T. Evans, Jr, Inorg. Chem., 1966, 5, 967; (e) V. W. Day, W. G. Klemperer and O. M. Yaghi, J. Am. Chem. Soc., 1989, 111, 5959; (f) D. Hou, K. S. Hagen and C. L. Hill, J. Am. Chem. Soc., 1992, 114, 5864; (g) A. Müller, M. Penk, R. Rohlfing, E. Krickemeyer and J. Döring, Angew. Chem., Int. Ed. Engl., 1990, 29, 926; (h) D. Hou, K. S. Hagen and C. J. Hill, J. Chem. Soc., Chem. Commun., 1993, 426-428; (i) Y. Chen, X. Gu, J. Peng, Z. Shi, H. Yu, E. Wang and N. Hu, Inorg. Chem. Commun., 2004, 7, 705; (j) Y. Hayashi, K. Fukuyama, T. Takatera and A. Uehara, Chem. Lett., 2000, 770; (k) G. K. Johnson and E. O. Schlemper, J. Am. Chem. Soc., 1978, 100, 3645; (l) A. Müller, M. Penk, E. Krickemeyer, H. Bögge and H. J. Walberg, Angew. Chem., Int. Ed. Engl., 1988, 27, 1719; (m) A. Müller, R. Rohlfing, J. Döring and M. Penk, Angew. Chem., Int. Ed. Engl., 1991, 30, 588.

4 (a) A. Müller, K. Hovemeier, E. Krickemeyer and H. Bögge, Angew. Chem., Int. Ed. Engl., 1995, 34, 779; (b) A. Müller, K. Hovemeier and R. Rohlfing, Angew. Chem., Int. Ed. Engl., 1992, 31, 1192; (c) A. Müller, Nature, 1991, 352, 115; (d) M. T. Pope, Nature, 1992, 355, 27; (e) L. Chen, F. L. Jiang, Z. Z. Lin, Y. F. Zhou, C. Y. Yue and M. C. Hong, J. Am. Chem. Soc., 2005, 127, 8588; $(f)$ A. Müller, H. Reuter and S. Dillinger, Angew. Chem., Int. Ed. Engl., 1995, 34, 2328; (g) A. Müller, R. Rohlfing, J. Döring and M. Penk, Angew. Chem., Int. Ed. Engl., 1991, 30, 588 .

5 (a) M. I. Khan, Y. Chang, O. Chen, H. Hope, S. Parking, D. P. Goshorn and J. Zubieta, Angew. Chem., Int. Ed. Engl., 1992, 31, 1197; (b) M. I. Khan and J. Zubieta, Angew. Chem., Int. Ed. Engl., 1994, 33, 760; (c) J. Salta, Q. Chen, Y. D. Chang and J. Zubieta, Angew. Chem., Int. Ed. Engl., 1994, 33, 757; (d) S. Konar and A. Clearfield, Inorg. Chem., 2008, 47, 3492.

6 (a) D. D. Heinrich, K. Folting, W. E. Streib, J. C. Huffman and G. Christou, J. Chem. Soc., Chem. Commun., 1989, 1411; (b) G. B. Karet, Z. Sun, D. D. Heinrich, J. K. McCusker, K. Folting, W. E. Streib, J. C. Huffman, D. N. Hendrickson and G. Christou, Inorg. Chem., 1996, 35, 6450.

7 (a) A. Müller, E. Krickmeyer, M. Penk, R. Rohlfing, A. Armatage and H. Bögge, Angew. Chem., Int. Ed. Engl., 1991, 30, 1674; (b) A. Müller, R. Rohlfing, E. Krickemeyer and H. Bögge, Angew. Chem., Int. Ed. Engl., 1993, 32, 909.
8 POM cryptands are bowl-shaped structures that act as receptors for anionic species whose guest-interactions are closely related to those found for organic crown ethers; POM carcarends are closed shell clusters that permanently entrap their guests; hemi-carcerands do not permanently entrap their guests

9 (a) P. Song, W. Guan, L. Yan, L. Chunguang, C. Yao and S. Zhongmin, Dalton Trans., 2010, 39, 3706; (b) M. M. Rohmer, J. Devémy, R. Wiest and M. Bénard, J. Am. Chem. Soc., 1996, 118, 13007.

10 (a) J. W. Han and C. L. Hill, J. Am. Chem. Soc., 2007, 129, 15094; (b) S. T. Zheng, J. Zhang, X. X. Li, W. H. Fang and G. Y. Yang, J. Am. Chem. Soc., 2010, 132, 15102; (c) N. V. Izarova, N. Vankova, A. Banerjee, G. B. Jameson, T. Heine, F. Schinle, O. Hampe and U. Kortz, Angew. Chem., Int. Ed., 2010, 49, 7807; (d) F. Xiao, J. Hao, J. Zhang, C. Lv, P. Yin, L. Wang and Y. Wei, J. Am. Chem. Soc., 2010, 132, 5956; (e) S. Khanra, M. Kloth, H. Massanatu, C. A. Muryn, F. Tuna, E. C. Sañudo, M. Helliwell, E. J. L. McInnes and R. E. P. Winpenny, Angew. Chem., Int. Ed., 2005, 44, 4187.

11 (a) W. Schmitt, J. P. Hill, S. Malik, C. A. Volkert, I. Ichinose, C. E. Anson and A. K. Powell, Angew. Chem., Int. Ed., 2005, 44, 7048; (b) G. La Spina, R. Clérac, E. S. Collins, T. McCabe, M. Venkatesan, I. Ichinose and W. Schmitt, Dalton Trans., 2007, 5248; (c) E. Baissa, A. Mandel, C. E. Anson and A. K. Powell, Angew. Chem., Int. Ed., 2001, 40, 3577; (d) I. McKeogh, J. P. Hill, E. S. Collins, T. McCabe, A. K. Powell and W. Schmitt, New J. Chem., 2007, 31, 1882.

12 (a) J. M. Breen and W. Schmitt, Angew. Chem., Int. Ed., 2008, 47, 6904; (b) C. I. Onet, L. Zhang, R. Clérac, J. B. Jean-Denis, M. Feeney, T. McCabe and W. Schmitt, Inorg. Chem., 2011, 50, 604; (c) L. Zhang and W. Schmitt, J. Am. Chem. Soc., 2011, 133, 11240.

13 (a) M. Yoshizama, M. Tamura and M. Fujita, Science, 2006, 312, 251; (b) R. M. Duke, E. B. Veale, F. M. Pfeffer, P. E. Kruger and T. Gunnlaugsson, Chem. Soc. Rev., 2010, 39, 3936; (c) V. M. TysselingMattiace, V. Sahni, K. L. Niece, D. Birch, C. Czeisler, M. G. Fehlings, S. I. Stupp and J. A. Kessler, J. Neurosci., 2008, 28, 3814.

14 A. Evangelou, Crit. Rev. Oncol. Hematol., 2002, 42, 249.

15 (a) S. Maria Nathwani, S. Butler, D. Fayne, N. N. McGovern, B. Sarkadi, M. J. Meegan, D. G. Lloyd, G. Campiani, M. Lawler and D. C. Williams, Cancer Chemother. Pharmacol., 2009, 66, 585; (b) S. M. Cloonan, J. J. Keating, S. G. Butler, A. J. S. Knox, A. M. Jørgensen, G. H. Peters, D. Rai, D. Corrigan, D. G. Lloyd, D. C. Williams and M. J. Meegan, Eur. J. Med. Chem., 2009, 44, 4862; (c) S. A. Bright, A. M. McElligott, J. W. O'Connell, L. O'Connor, P. Carroll, G. Campiani, M. W. Deininger, E. Conneally, M. Lawler, D. C. Williams and D. M. Zisterer, Br. J. Cancer, 2010, 102, 1474; (d) D. J. Giard, S. A. Aaronson, G. J. Todaro, P. Arnstein, J. H. Kersey, H. Dosik and W. P. Parks, J. Natl. Cancer Inst., 1973, 51, 1417; (e) M. P. Baker, A. G. Eliopoulos, L. S. Young, R. J. Armitage, C. D. Gregory and J. Gordon, Blood, 1998, 92, 2830; (f) C. B. Lozzio and B. B. Lozzio, Blood, 1975, 45, 321.

16 In order to take into account of the interactions between $\left\{\mathrm{V}_{5} \mathrm{O}_{9}\right\}$ complexes in $\mathbf{6}$ and 7, the following definition of the susceptibility has been used:

$$
\chi=\frac{\chi_{\mathrm{V}_{5}}}{1-\left(\frac{2 z J_{\mathrm{AF}}}{N g^{2} \mu_{\mathrm{B}}^{2}}\right) \chi_{\mathrm{V}_{5}}}
$$

See for example: (a) B. E. Myers, L. Berger and S. Friedberg, J. Appl. Phys., 1969, 40, 1149; (b) C. J. O'Connor, Prog. Inorg. Chem., 1982, 29, 203.

17 B. J. S. Johnson, R. C. Schroden, C. Zhu and A. Stein, Inorg. Chem., 2001, 40, 5972.

18 Z. Wang, J. M Heising and A. Clearfield, J. Am. Chem. Soc., 2003, 125, 10375 .

19 (a) Bruker SMART, version 5.629, Bruker-AXS Inc., Madison, WI, $1997-$ 2003; (b) Bruker SAINT-Plus, version 6.22, Bruker-AXS Inc., Madison, WI, 1997-2003; (c) Rigaku, CrystalClear, Rigaku Corporation, Tokyo, Japan, 2008.

20 G. M. Sheldrick, SHELXTL-NT, 5.1, Bruker Analytical X-ray Systems, Madison, WI, 1997

21 A. L. Spek, J. Appl. Crystallogr., 2003, 36, 7. 